\title{
SPECIAL FUNCTIONING ASPECTS OF CITY PASSENGER ROUTE TRANSPORT (BY THE EXAMPLE OF KREMECHUK)
}

\section{A. Markevich, A. Markevych}

Lanzhou Jiaotong University

88 West Anning Road, Lanzhou, Gansu 730070, P.R. China. E-mail: elena.markevych@gmail.com

Purpose. The paper presents the research results of organizational specifics of passenger transport functioning in Kremenchuk. The current situation in the passenger transport market in the city of Kremenchug is analyzed. Issues of using private capital in a limited budget fund, as well as sources of financing the transport complex, are considered. The prerequisites for creating real significant opportunities for the development and functioning of transport companies are considered. The issues of administrative influence on transport companies by state bodies, as well as transport services for social security beneficiaries are considered Methodology. To implement such a scheme, it is suggested an algorithm that providesfinancing for the necessary structure of the vehicle stock, allows for due diligence passenger traffic inspection, calculation of needed structure and scale of the vehicle stock, and its comparison with the existing one. Also, this algorithm helps to define the total investments, stagewise cash flow generation due to amortization, leasing, and budget funding. Findings. The general structure of urban passenger transport in Kremenchug is analyzed. The problem of the lack of centralized traffic control and the organization of transport carriers has been raised. Originality. The authors have studied the key problems of city transportation and presented its financing scheme through the launching of a joint-venture company that includes anordering customer and a transport operator. Practical value. The investigation conducted by the authors has revealed that the existing structure of the vehicle stock does not correspond to the city's needs, first of all, as for city bus type, which takes its toll for public transportation service quality and environment of the region. There is no centralized traffic and organization control of transport carriers, which results in work efficiency impairing for each of them. Conclusions. Having analyzed the research results obtained, we can summarize that the suggested model of the city public transport organization allows supporting funding of the necessary transport fleet structure and number of city buses.

Key words: public passenger vehicles, passenger transport functioning, financing, transport carrier.

\section{ОСОБЛИВОСТІ ФУНКЦІОНУВАННЯ МІСЬКОГО ПАСАЖИРСЬКОГО МАРШРУТНОГО ТРАНСПОРТУ (НА ПРИКЛАДІ КРЕМЕНЧУКА)}

\section{О. О. Маркевич, А. Г. Маркевич}

Ланьчжоуський транспортний університет

вул. Західний Аннин, 88, Ланьчжоу, Ганьсу, 730070, Китай. E-mail: elena.markevych@gmail.com

У статті представлено результати дослідження організаційних особливостей функціонування пасажирського транспорту в Кременчуці. Проаналізовано існуючу ситуація на ринку пасажирських транспортних перевезень в місті Кременчуці. Розглянуто питання використання приватного капіталу в умовах обмеженого бюджетного фонду, а також джерела фінансування транспортного комплексу. Розглянуто передумови для створення реальних значних можливостей розвитку і функціонування транспортних компаній. Розглянуто питання адміністративного впливу на транспортні компанії з боку державних органів, а також питання транспортного обслуговування для пільгових категорій населення. Проаналізована загальна структура міського пасажирського транспорту в Кременчуці. Досліджено основні проблеми відсутності централізованого контролю трафіку і організації транспортних перевізників. Автори вивчили ключові проблеми міського транспорту і представили схему його фінансування шляхом створення спільного підприємства, до складу якого входять замовник і транспортний перевізник. Для реалізації такої схеми пропонується алгоритм, який забезпечує фінансування необхідної структури парку транспортних засобів, дозволяе проводити комплексну перевірку пасажиропотоку, розраховувати необхідну структуру і кількості рухомого складу і порівнювати їх з існуючим. Крім того, цей алгоритм допомагає визначити загальні інвестиції, поетапне генерування грошових потоків за рахунок амортизації, лізингу та бюджетного фінансування. Проведене авторами дослідження показало, що існуюча структура запасів транспортних засобів не відповідає потребам міста, насамперед, щодо типу міських автобусів. В свою чергу відсутність централізованого контролю руху та організації транспортних перевізників призводить до зниження ефективності роботи для кожного з них. Проаналізувавши отримані результати досліджень, можна підсумувати, що запропонована модель міської організації громадського транспорту дозволяє підтримувати фінансування необхідної структури транспортного парку та кількості міських автобусів.

Ключові слова: громадський пасажирський транспорт, функціонування пасажирського транспорту, фінансування, транспортний перевізник.

PROBLEM STATEMENT. City public transport is one of the major factors in daily city life, that provides its effective functioning and combines different parts of the city into the one complex organism. Passenger transport makes vital contribution to the urban industrial infrastructure. Its stable and efficient operation is a part and parcel of the development and economic growth of the city and the reconstruction of it, as well as integrali- 
ty support and rising of living standards.

One of the particular features of the passenger transportation market lays in non-conformity of the existing structure of the vehicle stock to the current demands, first of all, as for city bus type, which corrodes much as service quality, so ecological situation of the region. At the current stage of economic development in Ukraine, public vehicle transport companies have faced with such difficulties as fleet renovation and modernization investment shortfall, inequitable-operation conditions for vehicle transport companies, irrelevance of the economic and organizational financing mechanism to contemporary conditions.

Among the research results published in this area for the recent two years, it should be mentioned the works of V. V. Braginskii [1, 2], Yu. B. Slobodyanik [3], V. F. Kharchenko [4], V. N. Parakhina [5], M. M. Moroz [6-9] and others.Nevertheless, none of these works was focused on congruence of interests of all the subjects of the passenger transportation market and development of the organizational and economic financial mechanisms of urban passenger transport. That is why investigation of the organizational problem of passenger transport in the city through the development of its organizational and economic financial mechanism, to harmonize the national interests with interests of the ordering customer and the transport carriers, seems to be a timely and important step.

The research is aimed to improve organization of the passenger transportation in the city, that implies the fleet renovation, enhances work efficiency of thecarryingcompanies as well as transport service quality.

MATERIAL AND RESULTS. The world practice revealed that in most countries authorities pay close and continued attention to the problems of functional organization of urban passenger transport, its funding resources and investment. While the budget fund is limited, procurement of private capital may be an effective way to solve wide range of urgent problems. Private funds can be raiseddue tocombined or municipal and private companies and making their business relations with local authorities in the form public private partnership (on a negotiation basis) with variable government take - from 10 to $100 \%$.

Today Ukraine hasenabling environment in the passenger vehicle transport market for the functioning of transport carriers who are the private entities, and strongly adverse conditions for the large scale companies, which forces theyto leave the market gradually. As a natural consequence, government loose control on service quantity and quality, technical conditions of the vehicle stock of a carrying company, and another disadvantage is that private carriers block free transport service for welfare beneficiaries.

These circumstances heavily complicate the way government bodies to make an administrative influence on vehicle transport nowadays. Government authorities should create the real significant opportunities for transport companies and accommodate the interests of any and all automobile transport participants - both carriers and passengers [10].

Municipal passenger transport in Kremenchuk is organized so to involve private-owned midi buses, light city buses, and minibuses for major transportation. Bus and trolleybus are the key type of transport there.

Great number of minibuses, including the privateowned ones, in thetransportation is a compulsory measure as the large-sized bus fleet has not been reequipped over the recent years. This is a natural result of shortfall of the carrying companies using large-sized buses for passenger transportation in the usual traffic condition. There are three major financial sources of a transport complex funding: local budget, income from its own transport enterprises, and subventions.

In Fig. 1 it is shown that number of light buses and minibuses raised dramatically in 2002, and up to 2006 they drove out almost all the large-sized buses.

In 2013, in Kremenchuk there were 27 bus services and 6 trolleybus services running correspondingly 301 buses as fixed-route taxis, with 61 buses in usual transportation mode among them, and 58 trolleybuses.

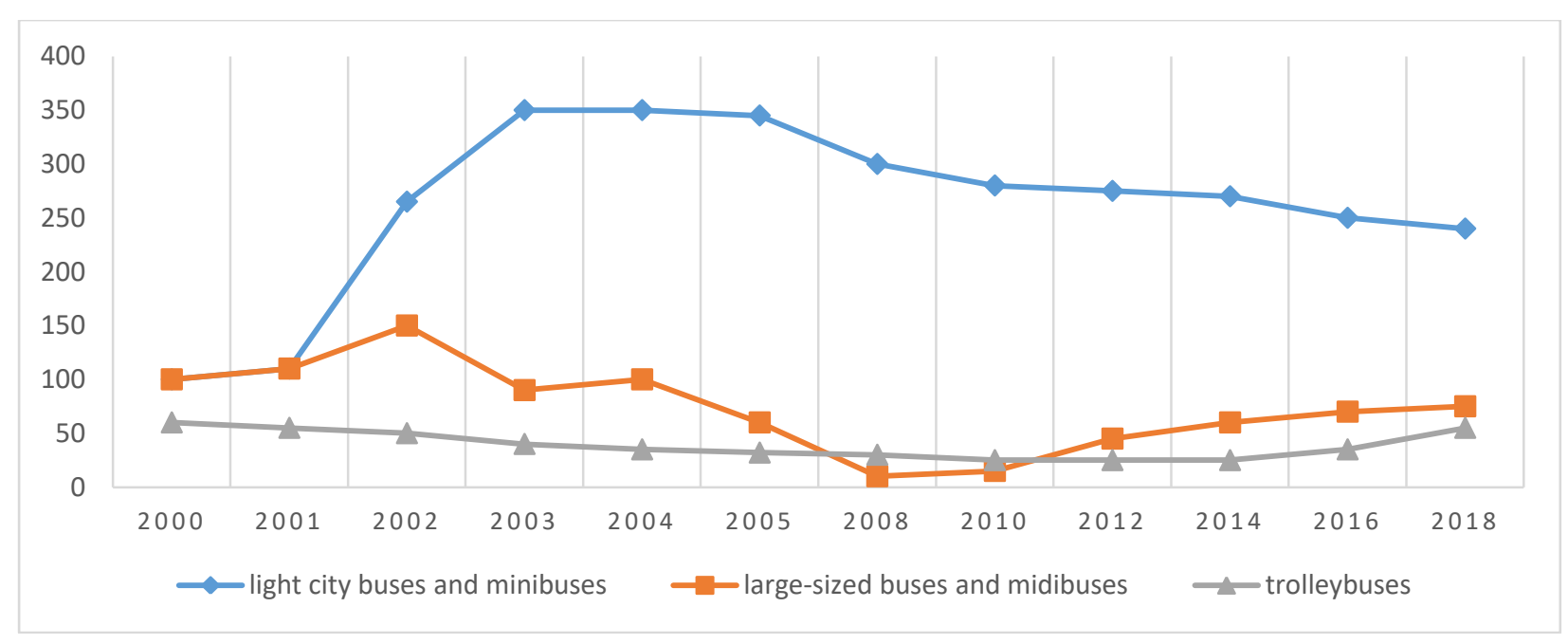

Figure 1 - The vehicle stock structure dynamics in Kremenchuk [11] 
In 2013 close attention was paid to support of the city's electric transport as an environmentally sound and socially vital type of transportation. «The Programme of municipal electric transport development in Kremenchuk for 2013-2015» was developed and approved, according to which in 2013, new trolleybuses were purchased to meet allo the comfort and safety requirements [12].

At present, 11 companies provide passenger transport service in Kremenchuk, among them there is a municipal enterprise, Kremenchuk Trolleybus Department, and a private company. And only three carriers provide compensatory financed transportation of welfare beneficiary citizens in Kremenchuk.For other city transport carriers there is no compensation in this case, despite they have an obligatory preferential seat in a saloon.

Organization and tax form currently existing at private carriers make an obstacle for them to have a subvention for welfare beneficiaries'transportation. To apply for governmental compensation, it is vitally important to find new organizational forms of the economic activity of enterprises that give the way to prepare submissions to obtain this compensation.

The main pressing problems of the transport operation are the lack of large-sized and midibuses and low renovation of the vehicle stock.

Economic and legislative conditions in the region have conduced raise of small businesses, growth of the vehicle stock while its type lowering. The investigation conducted by the authors has revealed that the existing structure of the vehicle stock does not correspond to the city's needs, first of all, as for city bus type, which takes its toll for public transportation service quality and environment of the region. There is no centralized traffic and organization control of transport carriers, which results in work efficiency impairing for each of them $[13,14,11]$.

Private-owned passenger transportation, on one hand, heavily complicates arrangement and control of urban passenger transport, and on the other hand, indicates that public transport becomes an investmentattractive industry due to availability of full rate of passenger-fareand quick money. These hard factors are to be noted when public transport improving. The primary task to be solved by municipal authorities in the case they involve private carrying companies is to provide high quality and effective passenger transportation. The conveyance terms for private-owned carriers must be flexible and accounting for social character of transportation [11].

Nowadays transportation in the city has a following arrangement scheme: Kremenchuk Municipal Councilre presented by City Transport ComplexDepartment is a customer. The transport carrier is an enterprise that operates a part of the city routes. This company can run its own vehicle fleet, which is on its own balance, or engage private traders who are the vehicle stock owners or have it on lease. In his turn, the trader may work as a driver himself or hire an employee [15].

As practice of functioning of the city public vehicle transport shows, its current interaction pattern ends in that functions of local authorities are mainly reduced to the carriageprocedure arrangement only: organization of competitive tenders and making of contracts. Monitoring and control of vehicle transportation companies reveal their inefficiency resulted from such interaction pattern where local authorities have scant leverage in influence on the private carriers and, thus, lose control of transportation processitself [16].

The public transport organizational system does not allow solving the major strategic concern of quality enhancement and safety of passenger transportation. Therefore, the transport organization system must be improved so to guarantee accumulation of funds for development of the problem of the vehicle stock renovation for it works more effectively. In this context, the authors have offered the optimal organizational model of urban passenger transport functioning to be created. The model's implementation is based on a proposed financing scheme of urban passenger transport (Fig. 2). This scheme is grounded on the interaction between a customer and a transport carrier who are supposed to establish a joint-venture company providing public transportation service in the city. 


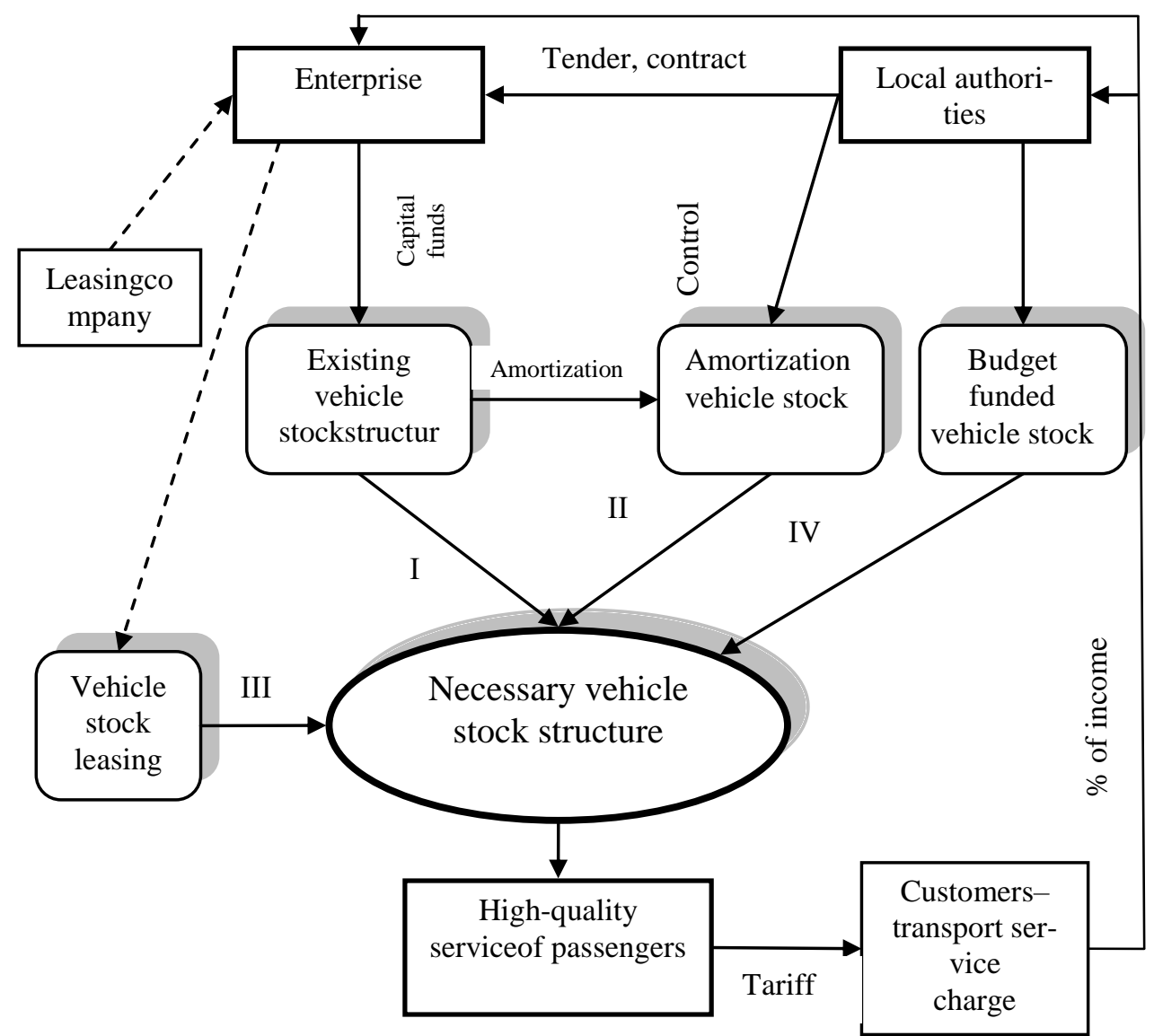

Figure 2 - The model of urban public transportfinancing

Nowadays reality makes it difficult for the wholescale financingfor both private carriers and local authorities. For that matter, old bus fleet is suggested to be renovated gradually.

Firstly, we should compare the bus fleet available with its needed structure, then we leave a fixed number of buses that becomes the vehicle stock and the first part of the structure required. Secondly, amortization of the remainingvehicle stock should earn a profit to purchase new large-sized and midibuses [15].

It is also suggested to purchase new buses of a required size type at the cost of private carriers under leasing agreements. For this end, the funds released from tax relief scheme should be applied. These buses become the third part of the sought structure.

On the final stage municipal authorities can acquire the rest of the needed buses at the budget expense, taking them on the balance of a municipal enterprise. This part is the fourth part. By this means we can get the whole sought structure of the vehicle stock. All the parts when summarized must amount to
$100 \%$ in total, which is the number of new buses. For the offered scheme of urban public transport financial organization to be implemented, the authors have worked out an algorithm of funding generation of needed structure of the vehicle stock (Fig. 3).

The algorithm presented implies regulatory monitoring of passenger flows, calculation of the necessary structure and number of the vehicle stock, and its comparing to the real one. Also, the algorithm includes defining of total of investments and progressive cash flows generation by means of amortization, lease and budget funding.

The calculation results are shown in the Table 1 . As they indicate, to purchase the bus fleet needed for Kremenchuk and so to meet the standards of quality transport service, the time span of required funding is up to four years. According to the functions imposed on both parties, private owners guarantee the major finance and management aspects of the enterprise, and local authorities, in return, guarantee enabling environment for public transportation organization and work of the transport carrying companies. 


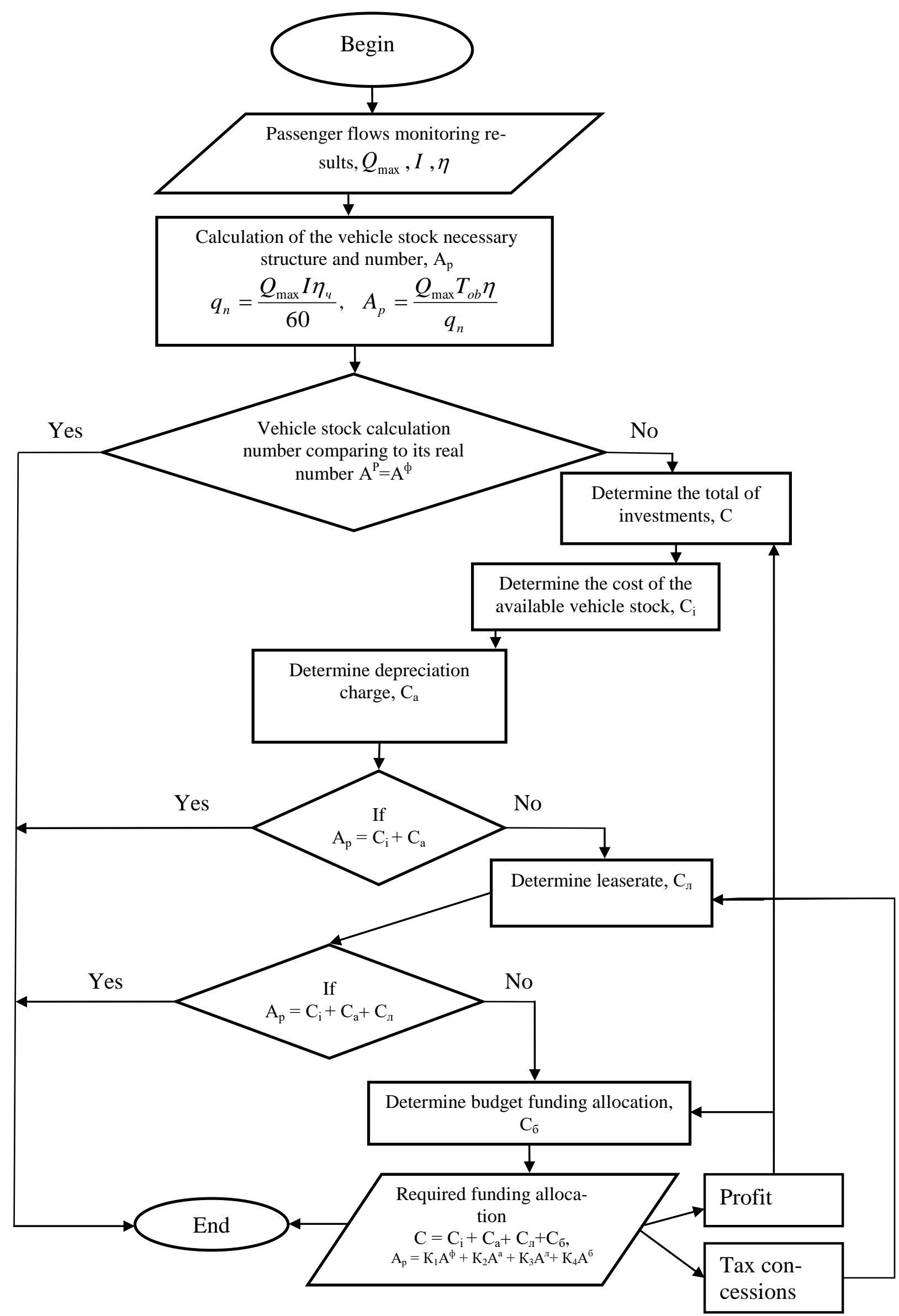

Figure 3 - An algorithm of funds generation of the necessary structure of the vehicle stock 
Table 1 - Generalized method and calculation results of funding allocation to urban public transport

\begin{tabular}{|c|c|c|}
\hline Criteria & Calculation formula & Conventional signs \\
\hline \multicolumn{3}{|c|}{ Determination of funding components } \\
\hline $\begin{array}{c}\text { Calculation of necessary } \\
\text { structure and number of the } \\
\text { vehicle stock }\end{array}$ & $\begin{array}{l}\text { According to the data of passenger flows } \\
\text { monitoring }\end{array}$ & - \\
\hline Investments & $\begin{array}{c}K=\sum C \cdot Q_{a} ; \\
K=45230930 \mathrm{UAH}\end{array}$ & $\begin{array}{c}K-\text { total investments,uah; } \\
C-\text { price of a bus of specified model, } \\
\text { uah.; } \\
Q_{a}-\text { number of buses of specified } \\
\text { model, uah }\end{array}$ \\
\hline $\begin{array}{l}\text { Cost of the vehicle stock } \\
\text { available }\end{array}$ & $\begin{array}{c}C=C_{n e p}-3 ; \\
C=40902000 \mathrm{UAH}\end{array}$ & $\begin{array}{l}C \text {-depreciated cost, uah; } \\
C_{\text {nep }} \text {-initial cost, uah; } \\
3 \text { - bus depreciation, uah }\end{array}$ \\
\hline $\begin{array}{c}\text { Cost of the vehicle stock up to } \\
\text { qualitystandards }\end{array}$ & $\begin{array}{c}\text { Comparison data } \\
C_{3}=8694000 \mathrm{UAH}\end{array}$ & $C_{3}-$ cost of thevehicle stock \\
\hline Amortization & $\begin{array}{l}A=\frac{C \cdot H_{a}}{100} \\
A=8180400\end{array}$ & $\begin{array}{c}A-\text { annual depreciation, uah; } \\
H_{a} \text { - depreciation charge, } 20 \%\end{array}$ \\
\hline $\begin{array}{l}\text { Leasepayments based on tax } \\
\text { deduction }\end{array}$ & $\begin{array}{c}L=\left(P-S \frac{1}{(1+i)^{n}}\right)\left(\frac{i}{1-(1+i)^{-n}}\right) \\
L=1078803\end{array}$ & $\begin{array}{c}L-\text {-lease payment,uah; } \\
P \text {-initial cost of leasing object,uah; } \\
S \text {-residual (cash surrender) valueof } \\
\text { leasing object, uah; } \\
n-\text { number of periods; } \\
i \text {-interest rate for the period; }\end{array}$ \\
\hline Budget funding & $C_{6}=K-A-L$ & \\
\hline \multicolumn{3}{|c|}{ Determination of fundingamount and timescale } \\
\hline Funding amount & $\begin{array}{c}Q_{f}=A+L+C_{6} \\
Q_{f}=8697920 \mathrm{UAH}\end{array}$ & $Q_{f}$-annual amount of funding, uah \\
\hline Time horizon & $\begin{array}{c}\Pi=\frac{K-C_{3}}{Q_{f}} \\
\Pi=4 \text { years }\end{array}$ & $\Pi-$ full funding period, years \\
\hline
\end{tabular}

Private carriers charge a passenger fare and vehicle maintenance service fee. Government executive bodies are to provide control of the carriers for them to abide by the terms of agreement and have the right for its termination, if non-compliance occurs. In such a fashion, the high quality control of intended use of amortization charges is achieved. Such an organizational form allows for companies to take the tax concessions; released funds, in their turn, can be targeted on the material and technical base renovation.

Terms for the material and technical base renovation are specified by the Tax Code for single tax payer enterprises. Hence, according to clauses 154.6 and 154, zero tax rate can be provided, if the monetary amount that was not transferred to the budget under zero tax rate is directed to rehabilitation of the material and technical base [17].

In this case, as a result of available tax concessions, the annual supplementary funds expected to acquire city buses are equal to UAH 1078803.

The transportation organization based on this model of city public vehicle transport company financing allows for more effective work of transport carrying enterprises in the conditions of variable tax legislation. The tax concessions give the opportunity to release the funds for the vehicle stock renovation as such release does not affect the cost value and, consequently, the fee rates. Alongside this, it conduces to accumulation and redistribution of amortization charges to purchase largesized buses and midibuses.

CONCLUSIONS. Having analyzed the research results obtained, we can summarize that the suggested model of the city public transport organization allows supporting funding of the necessary transport fleet structure and number of city buses. Old vehicle stock can be renovated gradually, during four years in a row. New vehicle stock will meet the passenger transportation demands in Kremenchuk providing high quality of public transport service and economic feasibility.

\section{REFERENCES}

1. Braginskii, V. V. (2011), "Istitutional support of transport service in Ukraine", State and the regions, no. 2, pp. 15-20.

2. Moroz, M. M., Korol, S. O., Boiko, Y. O. (2016), Social traffic monitoring in the city of Kremenchuk, Actual Problems of Economics, No 1(175), pp. 385398.

3. Slobodianik, Yu. B. (2007), Finansovyi mechanism funktsionuvannia pidpryemstv pasazhyrskogo 
avtotransportu $v$ suchasnykh umovakh [The finance mechanism of public vehicle transport companies operation in the present conditions]monograph, UABSNBU, Sumy, Ukraine, $158 \mathrm{p}$.

4. Vakulenko, K. E., Kharchenko, V. F. (2012), "On the city public transport routes quality service, East-European journal of advanced technologies, no. 4 (57), vol. 3, pp. 57-59.

5. Parakhina, V. N. (2007), Sovershenstvovanie upravleniya sistemo ipassazhirskogo transporta goroda [Management improvement of the urban public transport system], monograph, KNORUS, Moscow, Russia, $135 \mathrm{p}$.

6. Moroz, M. M., Levkovets', P. R., Moroz, O. V. (2010), Udoskonalennya perevezen' pasazhyriv m. Kremenchuk, Upravlinnya proektamy, systemnyy analiz i lohistyka: naukovyy zhurnal, No. 7, pp. 304-308.

7. Moroz, M. M. (2014), Udoskonalennya transportnoyi systemy pasazhyrs'kykh perevezen' m. Kremenchuk, Zbirnyk naukovykh prats' (haluzeve mashynobuduvannya, budivnytstvo). No. 2(41). pp. 156-164.

8. Moroz, M. M. (2014), Pidvyshchennya efektyvnosti tekhnolohichnoho protsesu transportnoho obsluhovuvannya m. Kremenchuk, Visnyk Natsional'noho tekhnichnoho universytetu «KHPI», No 43, pp. 103-109.

9. Moroz, M. M. (2015), Shlyakhy vdoskonalennya pasazhyrs'kykh perevezen' transportom zahal'noho korystuvannya, Zbirnyk naukovykh prats' Kirovohrads'koho natsional'noho tekhnichnoho universytetu «Tekhnika v sil's'kohospodars'komu vyrobnytstvi, haluzeve mashynobuduvannya, avtomatyzatsiya». Vyp. 28. pp. 57-63.

10. Sergienko, L. (2007), "To help a carrier and a passenger", The carrier, no. 9, pp. 5-6.

11. Moroz, O. V., Moroz, M. M. (2014), Specific features of city public transport financing (Kremenchuk case study). Actual Problems of Economics, 160(1), pp. 239-246.

12. Kremenchuk official site,[electronic source], available: http://www.kremen.gov.ua/zvt_pro_robotu_u _2019_rots_266/

13. Amosha, O. I., Filippova, O. S. (2010), "European practice in effective functioning management of urban public transport companies", Construction economics and economy, no. 4, vol. 6, pp. 179-189.

14. Moroz, M. M. (2015), Defining the term and the volume of investments on reduction to necessary structure of rolling stock of passenger public transport (Kremenchuk city case study), Actual Problems of Economics, Vol. 166 (4), pp. 235-243.

15. Velichko, V. V. " Up-to-date approaches to creation of the operation model of the companies of urban infrastructure transport, [electronic source], available at:http://eprints.kname.edu.ua/30174/1/32.pdf

16. Dolia, K. V. (2011), On the transport operation distribution in the urban public transportsystem", EastEuropean journal of advanced technologies, no. 3 (53), vol. 5, pp. 19-21.

17. Tax Code of Ukraine, [electronic source], availablet: http://zakon4.rada.gov.ua/laws/show/275517.

\section{ОСОБЕННОСТИ ФУНКЦИОНИРОВАНИЯ ГОРОДСКОГО ПАССАЖИРСКОГО МАРШРУТНОГО ТРАНСПОРТА (НА ПРИМЕРЕ КРЕМЕНЧУГА )}

\section{Е. А. Маркевич, А. Г. Маркевич}

Ланьчжоуский транспортний университет

ул. Западний Аннин, 88, Ланьчжоу, Ганьсу, 730070, Китай. E-mail: elena.markevych@gmail.com

В статье представлены результаты исследования организационных особенностей функционирования пассажирского транспорта в Кременчуге. Проанализирована существующая ситуация на рынке пассажирских транспортных перевозок в городе Кременчуге. Рассмотрены вопросы использования частного капитала в условиях ограниченного бюджетного фонда, а также источники финансирования транспортного комплекса. Рассмотрены предпосылки для создания реальных значительных возможностей развития и функционирования транспортных компаний. Рассмотрены вопросы административного влияния на транспортные компании со стороны государственных органов, а также вопросы транспортного обслуживания для льготных категорий населения. Проанализирована общая структура городского пассажирского транспорта в Кременчуге. Исследованы основные проблемы отсутствия централизованного контроля трафика и организации транспортных перевозчиков. Авторы изучили ключевые проблемы городского транспорта и представили схему его финансирования путем создания совместного предприятия, в состав которого входят заказчик и транспортный перевозчик. Для реализации такой схемы предлагается алгоритм, который обеспечивает финансирование необходимой структуры парка транспортных средств, позволяет проводить комплексную проверку пассажиропотока, рассчитывать необходимую структуру и количества подвижного состава и сравнивать их с существующим. Кроме того, этот алгоритм помогает определить общие инвестиции, поэтапное генерирование денежных потоков за счет амортизации, лизинга и бюджетного финансирования.

Ключевые слова: общественный пассажирский транспорт, финансирование, транспортный перевозчик, лизинг, инвестиции.

Стаття надійшла 30.05.2019. 